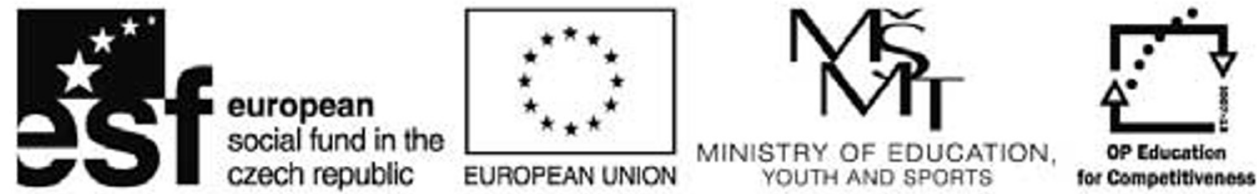

INVESTMENTS IN EDUCATION DEVELOPMENT

\title{
Post-doctoral studies - development of new methods and evaluation of compound pharmacokinetics parameters \\ University Hospital Hradec Králové, Czech Republic
}

Position description: University Hospital Hradec Králové, Biomedical Research Center (BRC), is looking for new $\mathrm{PhD}$ graduates with orientation on development of new analytical methods and assessments of validation of compound pharmacokinetics parameters. We are searching for unique person with broad scientific and management background in the process of development new therapeutic agents. Candidate will become the part of active scientific group and will be positioned as a principal investigator of projects in biomedical area. With other team members and students he/she will be able to participate in development of novel drugs.

This skilled scientist will play significant role in providing financial support from new projects for BRC and also high quality research outcomes are expected. The candidate must have already finished $\mathrm{PhD}$ study from chemistry, pharmacology, toxicology or other related subjects. Job description involves development of new methods for evaluation of pharmacokinetics parameters of potential drug candidates. The position also covers educational activity and responsibility for leading both pre-gradual and postdoctoral students. Excellent interpersonal skills, willingness and educational abilities are necessary for cooperation in multidisciplinary team.

Employer: University Hospital Hradec Králové, BRC, Czech Republic, Assoc. Prof. Kamil Kuča, PhD

Registration deadline: 28.6 .2012

Job beginning and duration period: $1.8 .2012 ; 35$ months; full-time job

Application form containing following belongings must be send to address: Odbor personálních vztahů, Fakultní nemocnice Hradec Králové, Sokolská 581, 50005 Hradec Králové, Czech Republic

Envelope must be clearly marked with inscription: "POSTDOC POSITION"

1) Structured CV with the list of IF publications of candidate within last 5 years.

2) List of posters and oral presentations at scientific conferences and foreign job experiences of candidate within last 5 years.

3) Confirmation of obtaining $\mathrm{PhD}$ degree in appropriate field of study after 28. 3. 2008.

4) Know-how of Czech or English language (native speaker/certificate STANAG 2 or similar at least).

5) At least two letters of recommendation describing candidate abilities and experiences with regard to proposed above mentioned analytical position.

In case of some obscurities please contact us at: dora.truncova@fnhk.cz 